\title{
Service Quality Determinants of Electricity Consumers in The Gambia
}

\author{
Sama Jawneh and Musa Manneh
}

\begin{abstract}
In a competitive market environment where goods and services are rendered to consumers, the quality of products has significant impact on its price. Competition in energy sector directly affects the nature and quality of service delivery to its consumers, thus the quality of service will greatly determine the level of satisfaction customers received from the quality of delivered service. To this effect, this study focus on the utility service industry through investing the determinants of service quality on customer satisfaction on the Gambian electricity service consumers - a case study of National Water and Electricity Company Limited (NAWEC). This paper also identifies key strategies that the utility service company can employ to increase its customer satisfaction. Using nonprobability convenience sampling, data was collected from 250 domestic consumers of electricity in the Gambia using selfadministered questionnaires. Descriptive statistics; Correlation and regression analysis were used to analyze the data through IBM SPSS statistics Version 20. The results of the regression analysis identify assurance, responsiveness and empathy as the top most consumer perceived service quality determinants of Gambian electricity consumers respectively. This implies that NAWEC should develop and implement excellent quality service delivery initiatives with much emphasis on service assurance, responsiveness and emotional empathy as well as business models and strategies gear towards consumerism, in addition to professional and competent staff recruitment and training. The result of which will significantly lead to an increase customer satisfaction for the corporation.
\end{abstract}

Index Terms - Determinants, Service Quality, NAWEC, Electricity Consumers.

\section{INTRODUCTION}

In today's competitive business environment, firms that are able to deliver high quality service by meeting or exceeding customer's expectation are expected to perform more than their rivals in the same industry [58]. This implies that, understanding service quality and customer satisfaction notion by corporations serve as a roadmap for building competitive advantage and growth against competitors in the market [1]. Services are defined as economic activities whose outputs are in a form of deeds, processes and performances rather than physical products [2]. According to [24] service can be defined as an action or an activity which can be offered by a party to another party, which is basically intangible and cannot affect any ownership. This

Published on August 3, 2020.

S. Jawneh, Ural Federal University and University of the Gambia, Gambia.

(corresponding e-mail: sjawneh@utg.edu.gm)

M. Manneh, Ural Federal University and University of the Gambia, Gambia.

(e-mail: musamanneh90@gmail.com) research added that, service may be related to tangible or intangible product, thus service is an assortment of how well a delivered service conforms to the client's expectations. Therefore, service business operators often assess the service quality provided to their customers in order to improve their service, to quickly identify problems and to better assess client satisfaction [17]. Given that services can satisfy clients' needs, they are viewed as products representing a wide range of intangible offerings that clients value and pay for in the market place [3]. Due to their intangibility, services are produced and consumed simultaneously with a focus dimension of offering quality service to customers.

The concept "service quality" as conceptualized in service marketing literature centers on perceived quality and has been defined as clients' judgment of an overall service experience [4]. In addition [5], [6] all alluded that, customer-perceived service quality is theoretically defined as the customers' experience on the actual service on several constituents of the service experience. Also, [7] stated that service quality is "just measuring of a particular service and also understanding the customer's expectation on the service". [8] mentioned similar definition. Despite being intangible, services are nonetheless able to provide added value to their clients or receivers just like tangible products [1]. Service quality is the backbone of customer satisfaction that is why most companies are focusing on service quality to satisfy and retain their customers [9]. Service quality does not only plays a role in retaining existing customers but also attracting new ones. In addition, Service quality and customer satisfaction are the most popular areas of research in assessing the quality service delivery of a firm [11]. Most of the previous researchers in the areas of service quality and its influence on customer satisfaction [10] were mostly centered on other service areas like banking and hospitality industries, but very limited in electricity utilities cooperation.

Furthermore, the studies of [12] affirm that good customer service is part of ensuring high service quality. Based on the assessment of service quality provided to the customers, business operators are able to identify problem quickly, improve their service and better assess client expectation. Service quality therefore, is a focused evaluation that reflects the customer's perception of specific dimensions of service namely reliability, responsiveness, assurance, empathy and tangibles [13].

Despite significant studies on service quality especially on hard core services like banking, tourism, insurance, transportation among a host of others but there is limited empirical research conducted on the service quality determinants in the energy industry, thus leaving the arena 
not fully explored although the few studies conducted confirmed that there is a relationship between service quality delivery of energy services and customer satisfaction. As a result, this study focuses specifically on electricity service industry to investigate the determinants of service quality of Gambian domestic consumers of electricity, the case of National Water and Electricity Company Limited (NAWEC).

Research problem: The characteristics of service make it one of the most difficult areas to handle. The quality of service may vary depending on the provider. This variance nature of service may have a significant impact on the customers. The quality of service provided to the customer determines their level of satisfaction. As electricity devastation continues to rise in the Gambia resulting to huge economic and human losses. Consequently, customers are becoming more worried about their safety, thus deems it prudent for service provider to account for the quality of service delivery to their clients. It is therefore timely for NAWEC as an energy service provider to consider the plight of its customers through service quality evaluation, thus the motivation and reason for this research.

\section{THEORETICAL BACKGROUND}

\section{A. What is Service Quality?}

Quality has been perceived in different perspectives by number of researchers. It can simply be defined as conformance to requirements that satisfies the customer. According to [19] quality of service(s) rendered to customers of electricity could be boosted by the level of competition, where a particular service supplier will have an edge over others in terms of quality service delivery and vice versa. This implies that with value addition to the services, the market entities will be more active in the industrial network resulting to the growth of countries national economy [20].

Further, [14] describe service quality as a relationship between customer perception and expectation over a particular service offering. It gauges whether the customers perception of a service met or surpassed what they expect prior to their encounter with the service delivered. While [15] viewed it as portion of customer attitude, perception, expectation as well as satisfaction over a specific service. [16] considered service quality as a "universal judgment or attitude, relating to the superiority of the service". They further alluded that Service quality presents "the consumer's overall impression of the relative lowliness or dominance of the organization and its services".

Service quality poses a significant boost on the performance of firms, thus makes it one of the key areas of devotion for many organizations in recent years [21]. This study further poised that companies that provide superior service quality are more likely to be valued by their customers as opposed to those offering inferior service delivery. This is established on the notion that customers measure the quality of service based on their perception of service experience against the expected service. [18] stressed that service aspect of the product is mostly neglected by marketers focusing more on the tangible components of products. This creates a gap which needs to be explored.

Studies conducted by [19] in Indian electricity utility sector provides a system designed framework in electricity utility service as per the customer requirements and has identified seven items which includes, quality of power supply, electric bills payment mode, complain handling, new connectivity, safety, voltage inconsistency and time management in bill payments, requires a significant adjustment and appropriate policy measures in order to boost up service quality in electricity sector. They further stressed the significant of the role of continuous customer service provision as a means to improving quality service delivery.

\section{B. Customer Satisfaction, Loyalty and Service Quality}

Customer loyalty is the tendency of customers repeating a purchase of particular product or service based on the satisfaction they received. According to [30] customers that are loyal have the propensity to be retained and thus generate profitability and growth for the firm and assure continuous survival of a firm. [24] defined customer loyalty as "a deeply held commitment to re-buy or re-patronize a preferred product or service in the future despite situational influences and marketing efforts having the potential to cause switching behavior ". Also, [25] expresses loyalty as the attachment a customer feels for a company's people, products and service delivery. While [26] describes a loyal customer as someone who engages in regular purchases of a firm's product at the same time refers others towards the company's products. In addition, [27] do not only define true customer loyalty to be based on their repeat purchase behavior but also their connection to a particular brand or firms.

[28] revealed that customer loyalty is based on customer's emotional commitment towards a particular brand or firms. In addition, [29], [2] all alluded that customer loyalty gives customers the desire to pay for the product on repeatedly basis and engaged in cross-buying intention of firms different brands. On the contrast, [22] stressed that loyal customers are not necessarily satisfied customers but satisfied customers tend to be loyal customers. Therefore, satisfaction can be summary as a psychological state resulting when the emotion surrounding disconfirmed expectations is coupled with the consumer's prior feelings about the consumption experience. [24] defined it as "a person's feelings of pleasure or disappointment resulting from comparing a product perceived performance or (outcome) in relation to his or her expectations". However, [31] claimed that "satisfaction is an overall customer attitude towards a service provider or an emotional reaction to the difference between what customers anticipate and what they receive, regarding the fulfillment of some need, goal or desire".

[32] stressed that customer satisfaction is based on the customer's judgment after purchase decision has been made, whereas [34] poised that it is based on the amount of interaction a customer has with the product which if it satisfies will make purchase decision vice versa. According to [36] customer satisfaction can be enhance through effective management of the appearance of sales people as being trust worthy with a high degree of expertise resulting 
to establishing long term business relationship. [37] added that satisfaction is a means for profit maximization, thus provide more dividend to shareholders and assurance of a firm's future growth. A firm's profitability is positively influenced by satisfaction of customers with repeat purchasing, loyalty and word of mouth advocacy [38].

Studies by [39] underscored that overall customer satisfaction is greatly influenced by the behavior of employees towards serving their customers which is perceived either negatively or positively. The enhancement of a firm's market share and its overall performance improvement according to [40] depends on its physical distribution process as a means to customer satisfaction. Furthermore, the findings of [41] revealed that employee attitude has a significant positive effect on customer satisfaction in the US grocery stores.

According to [42] customer satisfaction is prudent in creating competitive edge against competitors in the market, thus resulting to increase in shareholders wealth. Satisfied customers serve as an advocate through word-of-mouth to a firm, thus increasing their customer base [43], [44]. [45] asserted that word-of-mouth activities positively influence customer satisfaction, adding that when customers are satisfied they become more loyal than other customers in terms of repeat purchase intensions. [22] underscored that outstanding service level as compared to competitors is a means to achieve satisfaction and loyalty of customers. According to [47] "the relationship between satisfaction and loyalty on the Internet is moderated by involvement and partially mediated by trust". [46] asserted that customer satisfaction by firms serves as a means to secure funding from creditors.

Researchers in the power industry have also identified customer satisfaction to be a good attributed of power quality and reliability, customer service, company image, billing and payment, price and communications [48]. According to [19] customers of electricity expect consistency in the supply of electricity with very minimal power cuts.

\section{Determinants of Service Quality}

According to [32] service quality is regarded as the difference between customer's expectation and perception of service. This research added that the difference between perceived and actual service makes SERVQUAL a measure of attitude that has some degree of connection with satisfaction. This therefore creates a gap that determines the customer's perception of service quality either satisfied or dissatisfied. The SERVQUAL model by [18], [32] has recognized service quality into five scopes, however, for the purpose of this research two other determinants are added, thus a blended SERVQUAL model was adopted for the study. These variables are as follows:

Tangibility: According to [54] tangibility of service is defined to be physical facilities, appearances of employees plus equipment's of the firm and as well as the management team constitutes firms tangibility. [18] describe it as visible resources of a firm for service execution with the intention of satisfying customers. However, [53] adduced to the fact that modern sophisticated devices and anything a firm has which is visually appealing are regarded to be positive impact of tangibility thus resulting to customer satisfaction.

Empathy: Empathy is been defined by [54] as an individual attention accorded to a customer during or after the delivery of service. According to [32] customers becomes satisfied when their expectations are fully comprehended by a firm and a due customer service rendered without any tiresomeness in resolving their plights. [23] viewed empathy to be a process of enhancing communication between the company and its individual customers, to ascertain and provide the exact remedies to their unmet desires from the services rendered a means for customer satisfaction.

Responsiveness: The responsiveness of a firm describes the passion employees have in providing immediate services whenever required by customers [33]. In addition, [32] emphasized that enthusiastic employees provides customer delight when appropriate customer service are rendered on time without any difficulties. Responding to individual customer concern when needed and employees providing them with safety solutions on their issues makes them satisfied [17].

Reliability: [35] ascribed reliability to correct and consistent delivery of service as expected by the customer with the intention of satisfying. Reliability results to customer retention when service providers have the ability to uphold and accurately render to their customers the expected perceived service that they are looking for [33]. While [35] maintained that reliability has a significant impact on overall quality. Also [32] asserted that the basis for reliability in service quality for customer satisfaction is based on the ability of a firm to overcome any potential hindrance that may impede the timely delivery of the expected service and maintaining a high degree of error free.

Assurance: [54] have ascribed assurance to be employee's personality such as the knowledge and skills as well as positive conducts to gain customer trust in service delivery. In addition, [32] described assurance as the employee's abilities in satisfying their customers with the knowledge and skills they acquired to deliver effective and efficient service, a means for building trust and buoyancy between a firm and its customers. Assurance is the experience and professionalism conduct of a firm in its service delivery which results to an outcome of a positive image of the company and its employees in the minds of its customers, a means to satisfaction [49].

\section{Service Quality Dimension in Electricity Supply}

According to [50] the essence of power system is to provide consumers of electricity with consistent economic electric service. There are number of similar problems facing the power industries as alluded to by [55] in which service quality is not an exception. Therefore, the demand for good service delivery continues to be on the rise from the perspectives of customers of electricity [51]. As a result, [52] has proposed an efficient assessment and transmission optimization system based on combined data development analysis and principal component analysis. On the other hand, [55] focuses on control measures to improve on power system reliability, stability and security. Consequently, it is imperative to look at the application of service quality and how it impacts customer's satisfaction in electricity power sector using the blended SERVQUAL model. Therefore, the 
application of this model in the power sector requires investigating stability and security variables [19].

Stability: Power system stability is the ability of an electric power system for a given initial operating condition to regain a state of operating equilibrium after being subjected to a physical disturbance with most system variables bounded so that practically the entire system remains intact [51]. [49] has identified power system stability as an important factor for any secure system operation. In addition [52] has attributed major blackouts as instability of the power system which can result to customer dissatisfaction.

Security: According to [48] security of a power system refers to the degree of risk in its ability to survive imminent disturbances (contingencies) without interruption of customer service. It relates to robustness of the system to imminent disturbances and hence depends on the system operating condition as well as the contingent probability of disturbances [50]. Security threat which may result to disconnection is a means to customer dissatisfaction, preventive mitigating strategy such as additional reserve allocation, generator re-dispatch, re switching of lines, reactive power re-dispatch (capacitor switching) are means to preventing security hazards and improving customer satisfaction [49], [51].

\section{E. Electricity market of the Gambia}

The key stakeholders of the Gambia electricity sector are National Water and Electricity Company (NAWEC), the Public Utilities Regulatory Authority (PURA), the Ministry of Petroleum and Energy (MoPE). Electricity, Water and sewerage services in The Gambia are provided by NAWEC, a vertically integrated public utility corporation that handles generation, transmission and distribution of electricity as well as water production and distribution in addition to sewerage. The MoPE is responsible for the implementation of Government policy in relation to electricity supply and distribution among others through its utility sector regulator PURA. NAWEC first started as Gambia Utilities Corporation (GUC) in 1972 under the Utilities Corporation Act to supply and conserve electricity and water for the general public, industry and domestic households. Then 1993 over seen by Management Services Gambia Ltd. (MSG) and the Utilities Holding Corporation (UHC) which later combined to form NAWEC in 1996 [57] .

The Electricity Act of 2004 partially liberalized the electricity market specifically opening up electricity generation to independent producers. Currently, there are two independent power producers (IPPs) operating in The Gambia in addition to the cross boarder -interconnection from Senegal but Transmission and Distribution still remains the exclusive domain of NAWEC [56].

The corporation currently have two main power station in Kotu and Brikama supplying the main industrial areas of the country- Grater Banjul Area (GBA) while the seven (7) standalone diesel generators supplying the utility's rural customers. NAWEC operates on two types of meter system, credit and cash power. The former allows post payment of electricity bills while the latter is through prepayment at the various outlets or affiliated companies like the GSM communications and petrol station outlets. In addition,
NAWEC's customer base is segmented into both geographic (urban and rural) and user category (domestic and industrial) customers [58]. However, the focus of this study was on NAWEC's domestic customers of both urban and rural market segment.

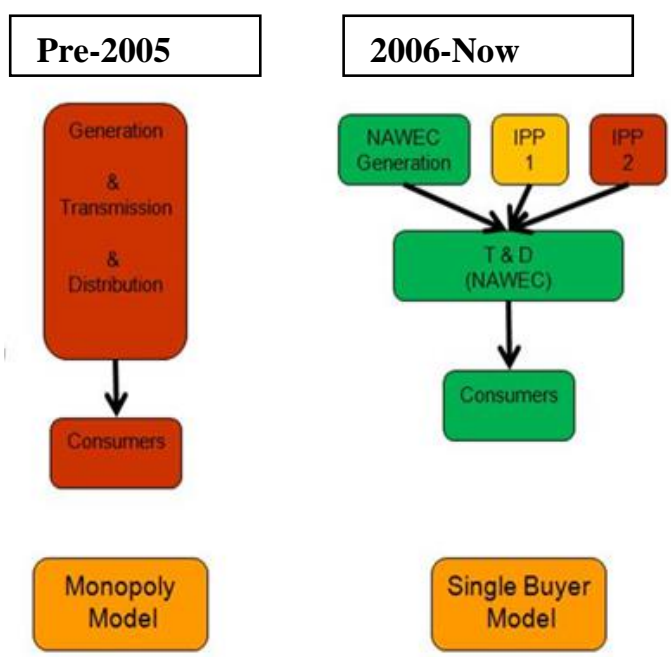

Fig. 1: Shift in Electricity Generation, Transmission and Distribution in the Gambia. Source Energy Data (G),2020

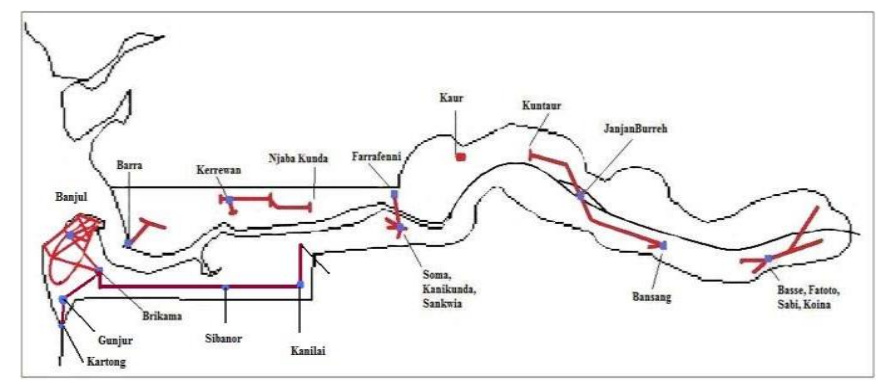

Fig. 2: Electricity Grid Infrastructural in The Gambia

Source: The Gambia Electricity Sector Roadmap, 2017

\section{Methodology}

\section{A. Research Design}

The aim of this research analysis was to examine the determinants of service quality of the electricity utility customers in the Gambia. The respondents are individual domestic consumers. The study employs a convenience sampling which is a non-probability sampling technique where respondents are selected based on their availability, accessibility, willingness and proximity to participate in the study. A sample size of 250 respondents was used in the survey. A Pearson correlation analysis was used to examine the direction, strength and significance of the variables relationships as well as multiple regressions. SPSS version 20 was used to analyze the data. The study was entirely conducted in English Language and all the questions of the constructs were obtained from previous literatures. The scale items in all constructs are at least three (3) questions as recommended by most researchers.

\section{B. Hypothesis Statement}

Based on the above scientific literature review, seven hypotheses statement were adapted to further test the validity and reliability of the variables. Table 1 shows that all the seven constructs were statistically significant with service quality (i.e. $\mathrm{p}<0.05$ ), thereby allowing us to confirm 
the hypotheses. The summary of the hypothesis statements adopted for this study are as follows:

\begin{tabular}{|c|c|c|}
\hline Hypotheses & Values Scored & $\begin{array}{l}\text { Determinatio } \\
\mathbf{n}\end{array}$ \\
\hline $\begin{array}{l}\mathbf{H}_{1:} \text { Tangibility has influence on } \\
\text { NAWEC Customer's perceive service } \\
\text { quality. }\end{array}$ & $\begin{array}{l}r=0.450 \\
p=0.000 \\
(p<0.05)\end{array}$ & Supported \\
\hline $\begin{array}{l}\mathbf{H}_{2:} \text { Empathy has influence on } \\
\text { NAWEC Customer's perceive service } \\
\text { quality. }\end{array}$ & $\begin{array}{l}r=0.596 \\
p=0.000 \\
(p<0.05)\end{array}$ & Supported \\
\hline $\begin{array}{l}\text { H3: Responsiveness has influence on } \\
\text { NAWEC Customer's perceive service } \\
\text { quality. }\end{array}$ & $\begin{array}{l}r=0.649 \\
p=0.000 \\
(p>0.05)\end{array}$ & Supported \\
\hline $\begin{array}{l}\text { H4: Reliability has influence on } \\
\text { NAWEC Customer's perceive service } \\
\text { quality. }\end{array}$ & $\begin{array}{l}r=0.579 \\
p=0.000 \\
(p<0.05)\end{array}$ & Supported \\
\hline $\begin{array}{l}\text { H5: Assurance has influence on } \\
\text { NAWEC Customer's perceive service } \\
\text { quality. }\end{array}$ & $\begin{array}{l}\mathrm{r}=0.657 \\
\mathrm{p}=0.000 \\
(\mathrm{p}<0.05)\end{array}$ & Supported \\
\hline $\begin{array}{l}\text { H6: Stability has influence on NAWEC } \\
\text { Customer's perceive service quality. }\end{array}$ & $\begin{array}{l}r=0.500 \\
p=0.000 \\
(p<0.05)\end{array}$ & Supported \\
\hline $\begin{array}{l}\text { H7: Security has influence on } \\
\text { NAWEC Customer's perceive service } \\
\text { quality. }\end{array}$ & $\begin{array}{l}\mathrm{r}=0.582 \\
\mathrm{p}=0.000 \\
(\mathrm{p}<0.05)\end{array}$ & Supported \\
\hline
\end{tabular}

\section{Reliability Test}

The reliability test for this study was quite imperative which enable the researchers to assess the relevance of the item scales used in the study (Table 1). A Cronbach's Alpha reliability score for Tangibility (0.903), Empathy (0.887), Responsiveness (0.890), Reliability (0.889), Assurance (0.885), Stability (0.899) and Security (0.899) are obtained from the study.

TABLE 2: Cronbach's Alpha values obtained from this study

\begin{tabular}{|c|c|c|}
\hline Scale Name & $\begin{array}{c}\text { Number of } \\
\text { Items }\end{array}$ & $\begin{array}{c}\text { Cronbach's } \\
\text { Alpha Value }\end{array}$ \\
\hline Tangibility & 5 & .903 \\
\hline Empathy & 3 & .887 \\
\hline Responsiveness & 3 & .890 \\
\hline Reliability & 4 & .889 \\
\hline Assurance & 3 & .885 \\
\hline Stability & 3 & .899 \\
\hline Security & 3 & .889 \\
\hline
\end{tabular}

\section{REsults And Discussion}

To evaluate the relationship between Tangibility, Empathy, Responsiveness, Reliability, Assurance, Stability and Security, a Pearson correlation analysis is used to measure the level of linear relationship between two constructs (Table 4). The correlation coefficient of all the constructs tested did not exceed 0.74 which shows that the constructs are disperse and do not overlap with each other.

Added to Pearson's correlation analysis, a multiple regression analysis was conducted to further test the seven hypotheses identified for this study. The results of analysis are presented below in Table 5 and Table 6 .

Furthermore, the stepwise regression model result indicates that Assurance has the highest influence on consumer perceived service quality with a standardized coefficient $\beta$ value of 0.658 . This is followed by Responsiveness with standardized coefficient $\beta$ value of
0.712 and finally Empathy with a standardized coefficient $\beta$ value of 0.728 . This study result is in tandem with the assertion of [19], [48], [49], [56]. Similarly, the study result of [20], [51], [52] share similar conclusion with this study. Furthermore, the highest Adjusted R2 value recorded 0.523 which show that this research constructs explains $(52 \%)$ of the determinants of perceive service quality of utility consumers in The Gambia. Moreover, this research finding revealed that, Gambian utility consumers are said to realize their value for money as well as gain satisfaction from ESCOs who give them assurance, responsiveness and show empathy during service delivery.

TABLE 3: Correlation Summary of the Determinants of Consumer Preference

\begin{tabular}{|l|l|l|}
\hline Constructs & Statistics & Consumer Preference \\
\hline Tangibility & Correlation & $0.450^{* *}$ \\
& Sig. (2-tailed) & 0.000 \\
\hline Empathy & Correlation & \\
& Sig. (2-tailed) & $0.596^{* *}$ \\
& Correlation & 0.000 \\
\hline Responsiveness & Sig. (2-tailed) & 0.000 \\
& & \\
\hline Reliability & Correlation & $0.579^{* *}$ \\
& Sig. (2-tailed) & 0.000 \\
\hline Assurance & Correlation & $0.657^{* *}$ \\
& Sig. (2-tailed) & 0.000 \\
\hline Stability & Correlation & $0.500^{* *}$ \\
& Sig. (2-tailed) & 0.000 \\
\hline Security & Correlation & $0.582^{* *}$ \\
& Sig. (2-tailed) & 0.000 \\
\hline
\end{tabular}

TABLE 4: Stepwise Multiple Regression Analysis.

\begin{tabular}{|c|c|c|c|c|c|c|}
\hline & \multirow[t]{2}{*}{ Model } & \multicolumn{2}{|c|}{$\begin{array}{l}\text { Unstandardized } \\
\text { Coefficients }\end{array}$} & \multirow{2}{*}{$\begin{array}{c}\text { Standardized } \\
\text { Coefficients } \\
\text { Beta }\end{array}$} & & \multirow[t]{2}{*}{ Sig. } \\
\hline & & B & $\begin{array}{l}\text { Std. } \\
\text { Error }\end{array}$ & & & \\
\hline \multirow[t]{2}{*}{1} & (Constant) & 1.304 & 0.167 & & 7.822 & 0.000 \\
\hline & Assurance & 0.602 & 0.049 & 0.658 & 12.281 & 0.000 \\
\hline \multirow[t]{3}{*}{2} & (Constant) & 0.825 & 0.179 & & 4.607 & 0.000 \\
\hline & Assurance & 0.398 & 0.059 & 0.435 & 6.730 & 0.000 \\
\hline & $\begin{array}{c}\text { Responsiv } \\
\text { eness }\end{array}$ & 0.362 & 0.067 & 0.351 & 5.434 & 0.000 \\
\hline \multirow{4}{*}{3} & (Constant) & 0.651 & 0.184 & & 3.546 & 0.000 \\
\hline & Assurance & 0.349 & 0.060 & 0.382 & 5.834 & 0.000 \\
\hline & $\begin{array}{c}\text { Responsiv } \\
\text { eness }\end{array}$ & 0.260 & 0.073 & 0.252 & 3.571 & 0.000 \\
\hline & Empathy & 0.085 & 0.027 & 0.208 & 3.150 & 0.002 \\
\hline
\end{tabular}

TABLE 5: Stepwise Regression Strength of the Relationship

\begin{tabular}{|c|c|c|c|c|}
\hline \multicolumn{5}{|c|}{ Model Summary $^{\mathrm{d}}$ (Stepwise method) } \\
\hline Model & $\mathrm{R}$ & $\begin{array}{c}\mathrm{R} \\
\text { Square }\end{array}$ & $\begin{array}{c}\text { Adjusted R } \\
\text { Square }\end{array}$ & $\begin{array}{c}\text { Std. Error } \\
\text { of the } \\
\text { Estimate }\end{array}$ \\
\hline 1 & $.658^{\mathrm{a}}$ & .432 & .430 & 1.00751 \\
\hline 2 & $.712^{\mathrm{b}}$ & .506 & .501 & .94194 \\
\hline 3 & $.728^{\mathrm{c}}$ & .530 & .523 & .92131 \\
\hline
\end{tabular}




\section{CONClusion AND ReCOMMENDATIONS}

\section{A. Conclusion}

The objective of this study is to examine the impact of service quality on the perceived customer satisfaction of Gambian electricity users generated by NAWEC. The results revealed that assurance, responsiveness and empathy are the topmost service quality determinants of utility industry valued by domestic consumers in the Gambia. In light of this both ESCOs and Utility regulators should develop and implement robust strategies and business models back by professional service delivery with focus on consumerism.

\section{B. Recommendations}

NAWEC and other Independent Power Producers (IPPs) should employ effective and efficient energy service delivery strategies with emphasis on service professionalism as well as employee ethical and moral behavior towards customers during service provision. This will give assurance and boost customer satisfaction. Also, ESCOs should provide responsive and enthusiastic customer safety solution through excellent customer care services. As a result, customer's emotional unmet needs will be fulfilled; this will give rise to enhancement of customer service quality and satisfaction.

\section{Research Contribution}

This research is the first scientific study that investigates the determinants of perceived service quality of utility consumers in the Gambia. Therefore, this study will benefit future researchers by establishing a knowledge base about utility service consumers for both Energy service Companies e.g. NAWEC and Utility regulator like Public Utility Regulatory Authority.

\section{Energy Service Companies (ESCOs)}

This study wills opportune ESCOs like NAWEC and future ones the knowledge base of utility service consumers perceive service quality in preferential order. This will help ESCOs to develop and implement befitting strategies that will enhance utility customer satisfaction as well as create competitive advantage for them.

Utility Regulators (PURA): This research findings will not only benefit utility service providers but also regulators like PURA by developing and implementing new energy business models with focus on consumerism.

\section{E. Limitation and Suggestion for Future Research}

This study used a convenience sample rather than a random sample i.e. the study adopts non- probability sampling instead of probability sampling. Therefore, future studies should use probability sampling like random or stratified sampling in order to generalize results obtained to a larger population.

Secondly, future studies should employ longitudinal survey rather than cross sectional survey because in cross sectional survey, data is collected at a single point of time from multiple cases but does not consider the issues of causality, so future studies should use longitudinal in which the researchers will administer a survey to one set of respondents over multiple time points and issues of causality can be determined.

Additionally, the survey used quantitative method which is based on questionnaires. One key benefit of using questionnaires or quantitative analysis is that hypotheses can be directly tested based on the empirical data collected from questionnaires. However, future studies should incorporate qualitative analysis which will further explore this research. In-depth interviews utilizing open-ended questions could allow for deeper exploration of these measures. Future researches should also focus on other group of respondents and lastly compare domestic versus commercial utility consumers in Gambia.

\section{ACKNOWLEDGEMENT}

We are very appreciative of the invaluable advice of the peer reviewers at the EJBMR. This work was supported by Act 211 of the Government of the Russian Federation, contract № 02.A03.21.0006.

\section{REFERENCES}

[1] P. Kotler (2003). Marketing Management: Analysis, Planning, Implementation and Control. 11th Ed, India: Prentice -Hall.

[2] V.A. Zeithaml \& M.J. Bitner (1996). Services Marketing, NY:McGraw-Hill.

[3] V.A. Zeithaml, M.J. Bitner \& D.D. Gremler (2006). Services Marketing: Integrating Customer Focus Across the Firm. NY: McGraw-Hill Irwin.

[4] G. Kang \& J. James (2004). "Service Quality Dimensions: an examinations: an examination of Gronroos's service quality model". Managing Service Quality. 14(4): 266-277.

[5] D. M. Szymanski \& R.T. Hise (2000). "E-satisfaction: an initial examination, "Journal of retailing, vol. 76, pp. 309-322.

[6] E. Lafuente, Y. Vaillant \& C.Serarols (2010). "Location decisions of knowledge-based entrepreneurs: Why some Catalan KISAs choose to be rural?" Tech. innovation, vol. 30, pp. 590600 .

[7] E. W. Anderson \& C. Fornell (2000). "Foundations of the American customer satisfaction index," Total Quality Management, vol. 11, pp. 869-882.

[8] E. Tsoukatos (2008). "Applying importance-performance analysis to assess service delivery performance: evidence from Greek insurance," EuroMed Journal of Business, vol. 3, pp. 144-162.

[9] P.R. Nayyar (1995). "Stock market reaction to customer service changes" strategic management journal, vol.16.No1,pp. 39-53.

[10] R.N. Bolton \& J.H. Drew (1991). A Longitudinal Analysis of the Impact of Service Changes on Customer Attitudes, Journal of Marketing, Vol. 55, Issue 1, 199.

[11] R. Germain \& M.B. Cooper (1990). Industrial Marketing Management, ISSN: 0019-8501, Vol: 19, Issue: 1, Page: 47-54

[12] J. Foster, S. Strasser \& A. Thompson (1992). The effect of written customer service policies on customer service implementation by carriers and shippers. Transportation Journal, 31(30), 4-10.

[13] V. A Zeithaml and M.J Bitner (2003). Services Marketing Integrating Customer Focus across the Firm. 3rd Edition, Irwin McGraw-Hill, New York

[14] J.A Czepiel (1990). "Service encounters and service relationships: implications for research". Journal of Business Research, 56:55-68.

[15] B.S. Sachdev and H.V. Verma (2004). Journal of Science Research, Vol.4 Number 1 (April-September 2004).

[16] A. Parasuraman., V. Zeithaml and L.L. Berry (1994). "Reassessment of expectations as a comparison standard in measuring service quality: implications for future research", Journal of Marketing, Vol. 58, pp. 111-24

[17] S. Brown and T. Swartz (1989). "A gap analysis of Professional Service Quality". Journal of Marketing 53(2):92-8.

[18] A. Parasuraman, V. A Zeithaml and L.L. Berry (1985). "A Conceptual Model of Service Quality and its Implications for Future Research". Journal of Marketing. 49:41-50.

[19] S. Satapathy, P.A. Mishra (2013). Customer oriented systematic framework to extract business strategy in Indian electricity services. J Ind Eng Int 9, 33 https://doi.org/10.1186/2251-712X-9-33.

[20] J. Dong, L. V. Shanlei, S. Xie, D. Xihao (2017) "Research on Value Sharing Model of Energy Service Industry Value Network" American Journal of Electrical Power and Energy Systems. Vol. 6, No. 4, pp. $51-56$. 
[21] M. Rahim, O. Mahamad \& T. Ramayah (2010), "Service Quality, Customer Satisfaction and Loyalty: A Test of Mediation" www.ccsenet.org/ibr International Business Research Vol. 3, No. 4.

[22] C. Fornell, S. Mithas , F.V. Morgeson \& M.S. Krishnan (2006) "Customer satisfaction and stock prices: High returns, low risk" Journal of Marketing , 70(1):3-14. 10.1509/jmkg.2006.70.1.3View Article Google Scholar.

[23] O. Richard (1981). "Measurement and Evaluation of Satisfaction Process in Retail Settings," Journal of Retailing, 57, pp 24-48.

[24] P. Kotler (2000), "Marketing Management" 10th edn. New Jersey, Prentice-Hall.

[25] C. Churchill (2000) "Banking on Customer Loyalty," Journal of Microfinance / ESR Review: Vol. 2: Iss. 2, Article 2. Available at: https://scholarsarchive.byu.edu/esr/vol2/iss2/2.

[26] C.E. Griffin (1995). International Relations and Politics. The Annals of the American Academy of Political and Social Science, 542(1), 222-223. https://doi.org/10.1177/0002716295542001018.

[27] A.S. Dick, K. Basu (1994). Customer loyalty: Toward an integrated conceptual framework. JAMS 22, 99-113 https://doi.org/10.1177/0092070394222001

[28] T. Xiaofei, T.J. Chou \& S. Chen (2008). "Effects of Guanxi investment on customer loyalty in Chinese market" 2(1):98-115.

[29] P.J. Danaher \& R.T. Rust (1996). "Indirect Financial Benefits from Service Quality". Quality Management Journal, Volume 3, 1996 Issue 2.

[30] C. Fornell (1992). "A National Customer Satisfaction Barometer: The Swedish Experience". Journal of Marketing, Vol. 56 No. 1, pp. 6 21.

[31] O.C. Hansemark \& M. Albinson (2004). "Customer Satisfaction and Retention: The Experiences of

[32] A. Parasuraman, V.A. Zeithaml and L.L. Berry (1988). "SERVQUAL: a multi-item scale for measuring consumer perceptions of service quality". Journal of Retailing. 12-40.

[33] G. Philip \& S.A. Hazlett (1997). "The measurement of service quality: a new P-C-P attributes model". International Journal of Quality and Reliability Management, 14(3):260286. Individual with Employees", Managing Service Quality, Vol. 14.

[34] Y. Yi (1989). A Critical Review of Consumer Satisfaction, Review of Marketing.

[35] V.A. Zeithaml. Chicago, American Marketing Association: 68-123.

[36] H. Annie, L. Mark \& P. Leach (2001). "Developing Loyal Customers with a Value-adding Sales Force: Examining Customer Satisfaction and the Perceived Credibility of Consultative Salespeople" The Journal of Personal Selling and Sales Management, Vol. 21, No. 2, pp. 147-156 Special Issue on Strategic Issues in Selling and Sales Management .

[37] S.G. Thomas and L.R. Lopo (2005). "Customer Satisfaction, Cash Flow, and Shareholder Value" Journal of Marketing, Vol. 69, No. 3, pp. $115-130$

[38] M. Zairi (2000). "Managing customer satisfaction: a best practice perspective", The TQM Magazine, Vol. 12 (6), pp.389-494.

[39] H.S. Kattara, D. Weheb \& O. A. El-Said (2008). The impact of employee behaviour on customers' service quality perceptions and overall satisfaction, Tourism and Hospitality Research Vol. 8, No. 4 Special Issue: Papers from the 17th Annual International CHME Research Conference, Strathclyde, pp. 309-323.

[40] E. I Daniel and B. J. La Londe (1994). "Modeling the Effects of Customer Service Performance on Purchase Intentions in the Channel" Journal of Marketing Theory and Practice, Vol. 2, No. 2. pp. 45-60.

[41] J. Prince \& D.H Simon (2009). Multimarket Contact and Service Quality: Evidence. from On-Time Performance in the US Airline Industry. Management Science 61(2):372-390

[42] M. D. Johnson and A. Herrmann (1998). "Taking a Customer Orientation” Die Unternehmung, Vol. 52, No. 3, pp. 131-143.

[43] W. Boulding, A. Kalra, R. Staelin \& V.A. Zeithaml (1993). A dynamic process model of service quality: From expectations to behavioral intentions. Journal of Marketing Research, 30(1):7-27. 10.2307/3172510View ArticleGoogle Scholar.

[44] A. B. Parasuram \& L. V. Zeithaml (1991). Refinement and reassessment of the SERVQUAL instrument. Journal of Retailing, Vol. 67

[45] K. Şimşek, O. Demirbağ (2017). Modeling Service Quality, Customer Satisfaction and Behavioral Intentions in Airline Industry: A SEM Approach. The Journal of International Scientific Researches, 2 (6), 11-29. DOI: 10.23834/isrjournal.341694.

[46] Anderson, E. W., \& Mansi, S. A. (2009). Does Customer Satisfaction Matter to Investors? Findings from the Bond Market. Journal of Marketing Research, 46(5), 703-714. https://doi.org/10.1509/jmkr.46.5.703
[47] J. A. Castañeda (2011). "Relationship Between Customer Satisfaction and Loyalty on the Internet" Journal of Business and Psychology,Vol. 26, No. 3, pp. 371-383

[48] J. D. Power and Associates Reports (2008). Residential gas utility satisfaction, http://www.jdpower.com/corporate/utilities/.

[49] H.E. Salmawy, Y. Kamelia, A. Shereen, M. Gamea and K. Hamdy (2010). "Tracking the Reliability indicators In the Egyptian Electric Power System", Proceedings of the 14th International Middle Eas Power Systems Conference (MEPCON'10), Cairo University, Egypt, December 19-21, 2010, Paper ID 246.

[50] G. Frazier (1999). Organizing and Managing Channels of Distribution. The Journal of the Academy of Marketing Science, Vol. 27.

[51] C. Chan, L. Steven C.Y Derek (1993). Interaction Free Energy between Plates with Charge Regulation: A Linearized Model. Journal of Colloid and Interface Science Volume 161, Issue 1, November 1993, Pages 260-264.

[52] A. Azadeh, S.M. Asadzadeh , M. Somayeh, (2011). Implementation of data envelopment analysis-genetic algorithm for improved performance assessment of transmission units in power industry. Int J. of Industrial and Systems Engineering, Vol.8.

[53] A.S. Fauziah (2012). "Evaluating the Relationship between Service Quality and Customer Satisfaction in the Australian Car Insurance Industry."

[54] J. W. T. Iwaarden, Jos (2002). A Study on the Applicability of SERVQUAL Dimensions of web Sites. Erasmus Research Institute of Management (ERIM), ERIM is the joint research institute of the Rotterdam School of Management, Erasmus University and the Erasmus School of Economics (ESE) at Erasmus Uni, Research Paper.

[55] A. Anthonisamy, A. Ramesh, R. B. Prabaharan (2010). Service quality gap analysis in private sector bank - a customer perspective. Proceedings of 20th International Business Research Conference 4 - 5 April 2013, Dubai, UAE, ISBN: 978-1-922069-22-1.

[56] M. Manneh \& S. M.R. Shams (2019) Energy Business in Gambia: An Industry Review for Theoretical and Practical Implications. In Thrassou A., Vrontis D., Weber Y., Shams S., Tsoukatos E. (eds) The Synergy of Business Theory and Practice. Palgrave Studies in Crossdisciplinary Business Research, In Association with EuroMed Academy of Business. Palgrave Macmillan, Cham https://doi.org/10.1007/978-3-030-17523-8_6.

[57] M. Manneh (2020a). Retail Marketing Of Imported Petroleum Products: Evidence From The Downstream Petroleum Sector Of The Gambia. European Journal of Business and Management Research, 5(4). DOI: http://dx.doi.org/10.24018/ejbmr.2020.5.4.365 https://doi.org/10.24018/ejbmr.2020.5.4.365

[58] M. Manneh, M. Kozhevnikov \& T. Chazova (2020b). Determinants of Consumer Preference for Petrol Consumption: The Case of Petro Retail in the Gambia. International Journal of Energy Production \& Management., Vol. 5, No. 2 (2020) 175-186

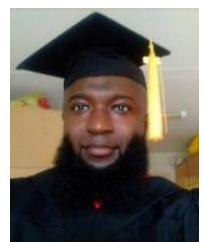

Mr. Sama Jawneh is a full-time instructor at the University of The Gambia, School of Business and Public Administration. Mr. Jawneh holds a BSc and an MSc in Management from the University of the Gambia and Ural Federal University, Russian Federation, respectively. Jawneh also acquired an expertise in energy business management. His research interest is in the areas of Consumer research, marketing communication, and strategic Management sciences.

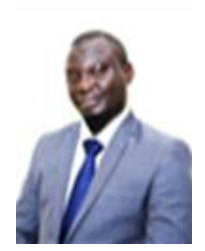

Mr. Musa Manneh is a Gambian by nationality and currently works as Reforms \& Modernization Officer at the Gambia Revenue Authority. He is also an adjunct lecturer at the School of Business and Public Administration of the University of the Gambia. Mr. Manneh holds a BSc and an MSc in Management from the University of the Gambia and Ural Federal University, Russian Federation, respectively. Manneh as well acquired an expertise in energy business management and he is a licensed management trainer by the National Accreditation and Quality Assurance Authority of The Gambia. He previously served as a General Manager of Better Future Production, a multimedia firm in Gambia and at the same time doubles as the Managing Director of Knowledge City Gambia Ltd., a subsidiary of the Knowledge City Vienna, Austria. Mr. Manneh's research interest relates to Energy Business, Risk Management, logistics and supply chain, and Social Entrepreneurship. 
